\title{
To what extent should we perform parametrectomy in FIGO stage IB cervical cancer?
}

FIGO evre IB serviks kanseri olgularında parametrektominin sinırları ne olmalıdır?

\author{
Ali Ayhan ${ }^{1}$, Eralp Başer ${ }^{1}$, Polat Dursun ${ }^{1}$, Asuman Nihan Haberal ${ }^{2}$ \\ 'Department of Obstetrics and Gynaecology, Division of Gynaecologic Oncology, Başkent University School of Medicine, \\ Ankara, Turkey \\ ${ }^{2}$ Department of Pathology, Basskent University School of Medicine, Ankara, Turkey
}

\section{Abstract}

Objective: To demonstrate the histopathological basis of individually tailored less radical surgery concept in patients with International Federation of Gynecology and Obstetrics (FIGO) stage IB cervical cancer.

Material and Methods: The study was performed in the gynaecologic oncology department of Başkent School of Medicine Hospital, Ankara, Turkey between January $1^{\text {st }} 2008$ and January $1^{\text {st }} 2009$. Cardinal and uterosacral ligaments were serially sectioned in an alternative approach, and were examined by a senior gynaecologic pathologist. Clinical and pathological features and findings in sections of uterine ligaments were recorded. Study data were analysed using the SPSS 17.0 program.

Results: Thirty-two out of 38 cases had squamous cell carcinoma (SCC) (84.2\%), and six had non-squamous cell tumours (15.8\%). Four cases had microscopic (10.5\%) and one case had macroscopic (2.6 $\%)$ tumour extension in cardinal ligaments. Mean tumour-free cardinal ligament length was $16.8 \pm 7.39 \mathrm{~mm}$. Presence of tumour invasion in cardinal ligaments correlated significantly with pelvic lymph node metastasis $(p=0.02)$. No isolated tumour deposits were found in any of the cases in serial sections of the cardinal or uterosacral ligaments. Conclusion: This research was designed as a preliminary study. Future studies are needed to determine the optimal resection margins of the uterine ligaments in surgically treated stage IB cervical cancer. With continuing research and the development of newer surgical techniques, patients' quality of life will be optimised accordingly.

(J Turkish-German Gynecol Assoc 2013; 14: 63-7)

Key words: Cervical cancer, radical hysterectomy, parametrectomy, histopathology

Received: 27 March, 2013

Accepted: 10 April, 2013
Özet

Amaç: Uluslararası Jinekoloji ve Obstetrik Federasyonu (FIGO) evre IB serviks kanseri olgularında hastaya özel belirlenen, daha az radikal cerrahi yaklaşımının histopatolojik temellerini ortaya koymaktır.

Gereç ve Yöntemler: Çalışma Başkent Üniversitesi Tıp Fakültesi Jinekolojik Onkoloji bilim dalında 1 Ocak 2008 ile 1 Ocak 2009 tarihleri arasında yürütülmüştür. Tip III histerektomi cerrahi spesimenlerindeki kardinal ve uterosakral ligamentler seri kesitler alınarak deneyimli bir jinekopatolog tarafından incelenmiştir. Olguların klinik ve patolojik verilerinin yanısıra, uterin ligamentlerin seri kesitlerindeki bulgular ortaya konulmuştur. Çalışma verilerinin istatistiksel analizi SPSS 17.0 programı ile yapılmıştır.

Bulgular: Çalışmaya dahil edilen 38 hastanın 32'sinde (\%84.2) skuamoz hücreli, geriye kalan 6'sında (\%15.8) skuamoz hücre dişı tümörler mevcuttu. Dört olguda (\%10.5) mikroskopik, bir olguda (\%2.6) da makroskopik olarak kardinal ligament tutulumu mevcuttu. Ortalama tümörsüz kardinal ligament uzunluğu $16.8 \pm 7.39$ mm idi. Kardinal ligamentlerde tümöral tutulum olması ile pelvik lenf nodu metastazı arasında anlamlı bir ilişki mevcuttu. Kardinal ve uterosakral ligamentlerin seri kesitlerinin hiçbirinde izole tümör depozitlerine rastlanmadı.

Sonuç: Bu araştırma, öncü bir çalışma olarak dizayn edildi. Cerrahi olarak tedavi edilen FIGO evre IB serviks kanserli hastalarda uterin ligamentlerin optimal rezeksiyon sınırlarının belirlenebilmesi için gelecek çalışmalara ihtiyaç vardır. Süren araştırmalar ve yeni cerrahi tekniklerin gelişmelerinin eşliğinde, hastaların yaşam kaliteleri de optimize edilecektir. (J Turkish-German Gynecol Assoc 2013; 14: 63-7)

Anahtar kelimeler: Serviks kanseri, radikal histerektomi, parametrektomi, histopatoloji

Geliş Tarihi: 27 Mart 2013

Kabul Tarihi: 10 Nisan 2013

\section{Introduction}

Radical abdominal hysterectomy (RAH) has been the traditional treatment in most cases of early stage cervical cancer (CC) for over a hundred years (1). In the class III RAH procedure, along with excision of the uterus, uterosacral ligaments are divided at their origin close to the sacrum, and cardinal ligaments are divided at the pelvic side-walls (2). Although extensive resection of the parametrial tissue ensures the highest probability of tumour removal, it is worth noting that these procedures carry a substantial risk for many subsequent complications, which are predominantly of genitourinary and

gastrointestinal origin. Sexual dysfunction is also not uncommon (3).

Considering the high survival rate of appropriately treated early stage CCs, it cannot be overemphasised that every effort should be made to avoid post-operative long term sequelae (3). The morbidities arising after extensive procedures have led us to search for ways to limit "radicality" without jeopardising oncological outcomes. In recent years, a remarkable trend towards less radical surgery in CC treatment has been observed in the literature. With the patients' quality of life (QOL) on focus, many investigators in the field have proposed various surgical techniques to lower mor-

Address for Correspondence: Eralp Başer, Department of Obstetrics and Gynaecology, Division of Gynecological Oncology, Başkent University School of Medicine, Ankara, Turkey Phone: +9053046027 74 e.mail: eralpbaser@gmail.com 
bidity (4-8). Moreover, various surgical classification systems have recently been proposed, which include nerve-sparing procedures $(9,10)$.

In this study, we examined the cardinal and uterosacral ligaments of specimens from class III radical hysterectomy procedures, all of which were performed for International Federation of Gynaecology and Obstetrics (FIGO) stage IB cervical cancer. Tissue analyses were performed thoroughly, utilising an alternative sectioning method. We searched for signs of isolated tumour involvement, and aimed to demonstrate the histopathological basis of currently evolving "less radical surgery" concept.

\section{Material and Methods}

The study was performed at the Gynaecological Oncology Department of Başkent University School of Medicine, between January $1^{\text {st }} 2008$ and January $1^{\text {st }} 2009$. Scientific and ethical approval was obtained from the institutional review board (KA11/08). The study was funded by Başkent University School of Medicine. Thirty-eight surgically treated cases of FIGO stage IB CC were prospectively included in the study. All procedures were performed by the same surgical team. In all of the procedures, bilateral pelvic and para-aortic lymph node dissection (LND) preceded class III RAH, excising the cardinal ligaments close to the pelvic sidewalls, and uterosacral ligaments close to the sacrum. Bilateral uterine arteries were ligated at their origin on the hypogastric vessels.

Operative specimens were immediately placed in a formaldehyde solution in the operating room, and were taken to the pathology laboratory. Conventional gross and histopathological examinations were performed initially. Histological type and dimensions of the tumour, depth of stromal invasion, lymphovascular space involvement (LVSI), microscopic parametrial and vaginal extension status and tumour-free parametrial length were recorded. Regional lymph nodes were examined for tumour involvement. The excised cardinal and uterosacral ligaments were serially divided into $3 \mathrm{~mm}$ sections from distal to proximal, perpendicular to the long axis of the ligaments. The slides were numbered and dyed with haematoxylin and eosin (H\&E) stain, and were examined by a senior gynaecological pathologist for any signs of tumour involvement. The study cases were subdivided into two groups with respect to tumour size: Group 1 for tumours $<4 \mathrm{~cm}$ and Group 2 for tumours $\geq 4 \mathrm{~cm}$. Evaluation of all cases together was followed by analysis according to groups.

Study data were analysed using SPSS version 17.0 statistical package program (Statistical Package for the Social Sciences, version 17.0, SPSS Inc., Chicago, IL, USA). Comparisons between groups were performed by using Pearson's chi-square or Fisher's exact test, Student's $t$ test and Mann-Whitney U test. $P$ values less than 0.05 were considered statistically significant.

\section{Results}

A total of 38 cases were included in the study. Twenty-five cases were in Group 1 and 13 cases were in Group 2. Mean patient age was $53.9 \pm 15.6$ (range 28-87). Thirty-two out of the 38 cases had squamous cell carcinoma (SCC) (84.2\%), and 6 had nonsquamous cell tumours (15.8\%). Four of the non-squamous group had adenocarcinoma and 2 had undifferentiated carcinoma. Mean tumour diameter was $3.2 \pm 1.7 \mathrm{~cm}$ (range 1.0-6 cm). Twelve cases (31.6\%) had pelvic or para-aortic lymph node metastasis. Perineural invasion was present in 5 cases (13.1\%). Clinical and pathological features of the cases are summarised in Table 1.

Four cases had microscopic (10.5\%) and one case $(2.6 \%)$ had macroscopic tumour extension in cardinal ligaments (Figure 1). Data regarding parametrial involvement is presented in Table 2. The presence of tumour invasion in cardinal ligaments correlated significantly with pelvic lymph node metastasis $(\mathrm{p}=0.02)$. Mean tumour size was higher in cases with parametrial involvement $(p=0.03)$. However, the parametrial involvement rate was comparable between Group 1 and Group 2 ( $p>0.05$ ).

The serial sections of cardinal ligaments were free of tumour deposits. Likewise, no tumour deposits were found in any of the cases in serial sections of the uterosacral ligaments.

\section{Discussion}

The oncological outcome of $\mathrm{CC}$ is generally favourable when diagnosed and treated at an early stage. However, many morbidities may arise after treatment, which ultimately result in the impairment of QOL (3). A number of therapeutic modalities have been suggested to prevent these undesired consequences of treatment $(4-7,11,12)$. Class II RAH instead of class III was proposed for the treatment of early stage CC nearly two decades ago (13). The authors claimed that excellent cancer control with less morbidity was possible in class II RAH. Since then, researchers have focused on seeking the optimal surgical technique in CC treatment. In the trial of Landoni et al. (14), 243 patients with Stage IB1-IIA CC were randomised to receive either class II or class III hysterectomy. Both groups had similar recurrence-free and overall survival rates, but there was less morbidity seen in the class II group. A study performed by Cai et al. (15) also favoured class II RAH rather than class III in grade I and II cervical SCCs smaller than $2 \mathrm{~cm}$. The authors reported similar oncological outcomes in the class II group, with significantly lower operating time, post-operative length of hospital stay, and estimated blood loss (15). It is worth noting that these two studies did not include stage IB2 cases. Individually tailored therapy for $\mathrm{CC}$ has also been defined, which deserves further evaluation $(4,16)$. A recently published study compared class I (extrafascial) hysterectomy versus class III RAH in stage IB1- IIA $\mathrm{CC}$ (8). Strikingly, there were no significant differences in recurrence rate and overall survival among extrafascial hysterectomy and class III RAH groups. Schmeler et al. (17) also published an extensive review on the conservative management of early stage cervical cancer. The authors focused on the current evidence that, in the presence of favourable pathological characteristics, a very low number of patients had parametrial tumour involvement. They concluded that, with sound data obtained from currently on-going studies, conservative treatment could be the standard approach in early stage CCs. 
Table 1. Clinicopathological data of study cases

\begin{tabular}{|c|c|c|c|c|}
\hline Parameter & $\begin{array}{c}\text { All cases } \\
\mathbf{n}: 38 \\
(\%)^{1}\end{array}$ & $\begin{array}{c}\text { Group } 1 \\
\text { n:25 } \\
(\%)^{1}\end{array}$ & $\begin{array}{c}\text { Group } 2 \\
\text { n:13 } \\
(\%)^{1}\end{array}$ & $\mathbf{p}^{2}$ \\
\hline Mean age $( \pm$ SD) & $53.9 \pm 15.6$ & $57 \pm 16.9$ & $47.7 \pm 10.9$ & 0.08 \\
\hline Mean tumour diameter in $\mathrm{cm}( \pm \mathrm{SD})$ & $3.2 \pm 1.7$ & $2.1 \pm 0.9$ & $5.1 \pm 0.8$ & $<0.001$ \\
\hline \multicolumn{5}{|l|}{ Surgery } \\
\hline - RAH + RLND & $11(28.9)$ & $5(20)$ & $6(46.2)$ & \multirow[t]{2}{*}{0.13} \\
\hline$-\mathrm{RAH}+\mathrm{RLND}+\mathrm{BSO}$ & $27(71.1)$ & $20(80)$ & $7(53.8)$ & \\
\hline \multicolumn{5}{|l|}{ Histological Type } \\
\hline - Squamous & $32(84.2)$ & $20(80)$ & $12(92.3)$ & \multirow[t]{2}{*}{0.64} \\
\hline - Non-squamous & $6(15.8)$ & $5(20)$ & $1(7.7)$ & \\
\hline \multicolumn{5}{|l|}{ Primary Tumour Size } \\
\hline$-<4 \mathrm{~cm}$ & $25(65.8)$ & $25(100)$ & 0 & \\
\hline$-\geq 4 \mathrm{~cm}$ & $13(34.2)$ & 0 & $13(100)$ & \\
\hline \multicolumn{5}{|l|}{ Parametrial Involvement } \\
\hline - Present & $5(13.2)$ & $23(92)$ & $10(76.9)$ & \multirow[t]{2}{*}{0.31} \\
\hline - Absent & $33(86.8)$ & $2(8)$ & $3(23.1)$ & \\
\hline \multicolumn{5}{|l|}{ Lymph Node Metastasis } \\
\hline - Absent & $26(68.4)$ & $19(76)$ & $7(53.8)$ & \multirow{3}{*}{0.27} \\
\hline - Only Pelvic & $11(28.9)$ & $6(24)$ & $5(38.4)$ & \\
\hline - Pelvic + Paraaortic & $1(2.6)$ & 0 & $1(7.8)$ & \\
\hline \multicolumn{5}{|l|}{ LVSI } \\
\hline - Absent & $18(47.4)$ & $17(68)$ & $3(23.1)$ & \multirow[t]{2}{*}{0.01} \\
\hline - Present & $20(52.6)$ & $8(32)$ & $10(76.9)$ & \\
\hline \multicolumn{5}{|c|}{$\begin{array}{l}{ }^{1} \text { Column percentage } \\
{ }^{2} \text { Comparison between Group } 1 \text { and Group } 2 \\
\text { "RAH: radical abdominal hysterectomy; RLND: Regional lymph node dissection; BSO: Bilateral salpingo-oophorectomy; LVSI: Lymphovascular space } \\
\text { involvement }\end{array}$} \\
\hline
\end{tabular}

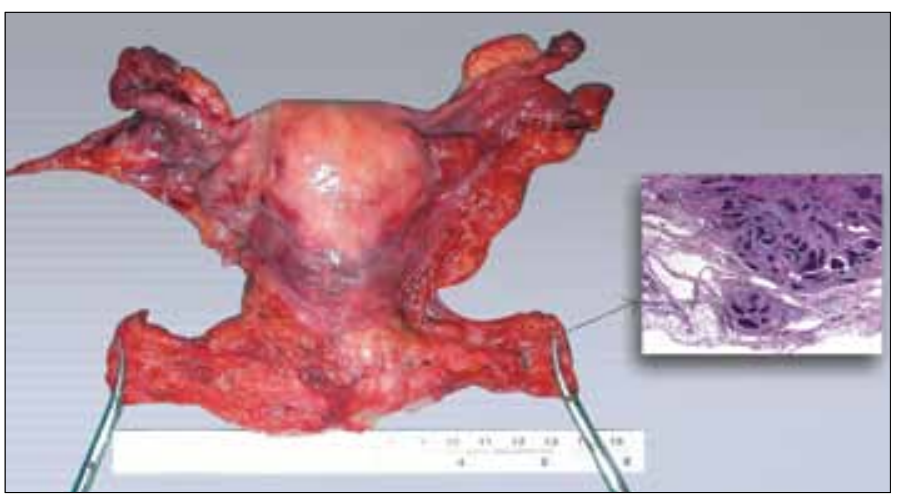

Figure 1. Pathological specimen after radical operation

In this study, we intended to demonstrate the histopathological findings of the major uterine ligaments comprising the parametrium of thirty-eight cases with FIGO stage IB CC. To the best of our knowledge, this is one of the few studies reported recently that investigate uterine ligaments thoroughly in surgically treated CC. Thus, it may serve as a preliminary report to guide future studies. All of the study cases underwent class III radical hysterectomy and pelvic-paraaortic LND. To obtain accurate results according to tumour size, we divided the cases into two groups and carried out analyses accordingly. It was interesting that there was no statistically significant difference between Group 1 and Group 2 regarding pelvic-paraaortic lymph node metastasis and parametrial involvement frequencies. However, mean tumour diameter was larger in cases with parametrial involvement. Although primary surgery is controversial in cases with tumours larger than $4 \mathrm{~cm}$, the maximum tumour size in our subset of cases (Group 2) was $6 \mathrm{~cm}$ and the patients preferred primary surgery. We purposefully included these cases in the study to provide information on larger-sized tumours. In our study, we could not demonstrate any sign of isolated tumour spread or lateral segment involvement of cardinal ligaments in any of the cases. One of the cases had $1 \mathrm{~cm}$ macroscopic cardinal ligament invasion, which was missed on preoperative evaluation but was evident on intraoperative exploration. The cardinal ligaments in that case were extensively excised, leaving at least $1 \mathrm{~cm}$ of tumour-free parametrium. A previous article by Hoffman et al. (18) reported the findings in completely excised vascular segments of radical hysterectomy 
Table 2. Data regarding parametrial involvement

\begin{tabular}{|c|c|c|c|c|}
\hline $\begin{array}{l}\text { Parameter } \\
\text { n:38 } \\
(\%) a\end{array}$ & $\begin{array}{c}\text { All cases } \\
\text { n:25 } \\
(\%) \text { a }\end{array}$ & $\begin{array}{c}\text { Group } 1 \\
\text { n:13 } \\
(\%) \text { a }\end{array}$ & Group 2 & $\mathbf{p}^{*}$ \\
\hline - Absent & $33(86.8)$ & $23(92)$ & $10(76.9)$ & \multirow[b]{2}{*}{0.31} \\
\hline - Microscopic & $4(10.5)$ & $2(8)$ & $2(15.4)$ & \\
\hline Tumour-free parametrium (mm) & $16.8 \pm 7.4$ & $10.5 \pm 0.7$ & $21.0 \pm 6.5$ & 0.10 \\
\hline
\end{tabular}

specimens. In this study, 1 case was FIGO stage IA2, 45 cases were stage IB1, 31 cases were stage IB2 and 7 cases were stage IIA. In 84 cases, 19 women had nodal (parametrial lymph nodes) or non-nodal (LVSI or discontinuous tumour cells) vascular segment disease, of which 7 were in the lateral segment. The authors concluded that, although there may be subgroup of $\mathrm{CC}$ cases with isolated medial parametrial metastasis that are appropriate for modified parametrial resection, cases with preoperative high risk features (large tumour, vaginal involvement, extensive LVSI, deep stromal invasion) should be treated by complete resection of the vascular portion of the cardinal ligament and LND. When the cardinal ligaments are predominantly involved in cervical tumour extension, it is worth remembering that these ligaments constitute the main route of $\mathrm{CC}$ spread, primarily via lymphatic circulation $(19,20)$. Although there are aforementioned publications that report equivalent therapeutic results in both class II and class III radical hysterectomies in early stage CCs, the probability of leaving residual disease should always be kept in mind (18). Many authors recommend at least $1 \mathrm{~cm}$ of tumour-free resection margins, where possible. However, the safest margin of resection needs to be defined by future studies.

There was no evidence of tumour involvement in uterosacral ligaments in this study. This finding is noteworthy, as almost complete excision of these ligaments is performed in class III $\mathrm{RAH}$. If confirmed by future studies, it may be more feasible to divide the uterosacral ligaments closer to the uterus.

This was a preliminary study that was conducted on a limited sample size. Future studies with larger sample sizes are needed to reach a final conclusion. Almost every gynaecological oncologist would agree that limiting the extent of cancer surgery should never impair oncological outcomes. With continuing research and the development of newer surgical techniques, patients' quality of life will be optimised accordingly.

Ethics Committee Approval: Ethics committee approval was obtained from Başkent University Institutional Review Board (KA11/08).

Informed Consent: Informed consent was obtained from all study participants.

Peer-review: Externally peer-reviewed.
Author contributions: Concept - A.A., E.B., P.D.; Design - A.A., E.B., P.D., A.N.H.; Supervision - A.A., E.B., P.D.; Resource - E.B., A.N.H.; Materials - E.B., A.N.H.; Data Collection\&/or Processing - E.B., A.N.H.; Analysis\&/or Interpretation - E.B., A.N.H.; Literature Search - E.B.; Writing - A.A., E.B., P.D.; Critical Reviews - A.A., E.B., P.D.

Conflict of Interest: No conflict of interest was declared by the authors.

Financial Disclosure: This study was funded by Başkent University School of Medicine.

\section{References}

1. Berkeley C, Bonney V. On the Radical Abdominal Operation for Carcinoma of the Cervix ("Wertheim's"), with Notes of Eighteen Cases, of Which Sixteen Were Too Advanced for Vaginal Hysterectomy. Br Med J 1908; 2: 961-7. [CrossRef]

2. Piver MS, Rutledge F, Smith JP. Five classes of extended hysterectomy for women with cervical cancer. Obstet Gynecol 1974; 44: 265-72.

3. Kenter GG, Ansink AC, Heintz AP, Aartsen EJ, Delemarre JF, Hart AA. Carcinoma of the uterine cervix stage I and IIA: results of surgical treatment: complications, recurrence and survival. Eur J Surg Oncol 1989; 15: 55-60.

4. Rob L, Halaska M, Robova H. Nerve-sparing and individually tailored surgery for cervical cancer. Lancet Oncol 2010; 11: 292-301. [CrossRef]

5. Hertel H, Kohler C, Michels W, Possover M, Tozzi R, Schneider A. Laparoscopic-assisted radical vaginal hysterectomy (LARVH): prospective evaluation of 200 patients with cervical cancer. Gynecol Oncol 2003; 90: 505-11. [CrossRef]

6. Raspagliesi F, Ditto A, Fontanelli R, Solima E, Hanozet F, Zanaboni $F$, et al. Nerve-sparing radical hysterectomy: a surgical technique for preserving the autonomic hypogastric nerve. Gynecol Oncol 2004; 93: 307-14. [CrossRef]

7. Sakuragi N, Todo Y, Kudo M, Yamamoto R, Sato T. A systematic nerve-sparing radical hysterectomy technique in invasive cervical cancer for preserving postsurgical bladder function. Int $\mathrm{J}$ Gynecol Cancer 2005; 15: 389-97. [CrossRef]

8. Landoni F, Maneo A, Zapardiel I, Zanagnolo V, Mangioni C. Class I versus class III radical hysterectomy in stage IB1-IIA cervical cancer. A prospective randomized study. Eur J Surg Oncol 2012; 38: 203-9. [CrossRef]

9. Querleu D, Morrow CP. Classification of radical hysterectomy. Lancet Oncol 2008; 9: 297-303. [CrossRef]

10. Cibula D, Abu-Rustum NR, Benedetti-Panici P, Kohler C, Raspagliesi F, Querleu D, et al. New classification system of radical hysterectomy: emphasis on a three-dimensional anatomic template for parametrial resection. Gynecol Oncol 2011; 122: 264-8. [CrossRef] 
11. Charoenkwan K, Srisomboon J, Suprasert P, Tantipalakorn C, Kietpeerakool C. Nerve-sparing class III radical hysterectomy: a modified technique to spare the pelvic autonomic nerves without compromising radicality. Int J Gynecol Cancer 2006; 16: 1705-12. [CrossRef]

12. Hoffman MS. Extent of radical hysterectomy: evolving emphasis. Gynecol Oncol 2004; 94: 1-9. [CrossRef]

13. Photopulos GJ, Zwaag RV. Class II radical hysterectomy shows less morbidity and good treatment efficacy compared to class III. Gynecol Oncol 1991; 40: 21-4. [CrossRef]

14. Landoni F, Maneo A, Cormio G, Perego P, Milani R, Caruso O, et al. Class II versus class III radical hysterectomy in stage IB-IIA cervical cancer: a prospective randomized study. Gynecol Oncol 2001; 80: 3-12. [CrossRef]

15. Cai HB, Chen HZ, Zhou YF, Lie DM, Hou HY. Class II radical hysterectomy in low-risk IB squamous cell carcinoma of cervix: a safe and effective option. Int J Gynecol Cancer 2009; 19: 46-9. [CrossRef]
16. Hoffman MS, Cardosi RJ. Intraoperative measurements to determine the extent of radical hysterectomy. Gynecol Oncol 2002; 87: 281-6. [CrossRef]

17. Schmeler KM, Frumovitz M, Ramirez PT. Conservative management of early stage cervical cancer: is there a role for less radical surgery? Gynecol Oncol 2011; 120: 321-5. [CrossRef]

18. Hoffman MS, Williams V, Salihu HM, Gunasekaran S, Sayer RA, Hakam A, et al. The vascular portion of the cardinal ligament: surgical significance during radical hysterectomy for cervical cancer. Am J Obstet Gynecol 2008; 199: 191 e1-7; discussion e7.

19. Henriksen $\mathrm{E}$. The lymphatic spread of carcinoma of the cervix and of the body of the uterus; a study of 420 necropsies. Am J Obstet Gynecol 1949; 58: 924-42.

20. Holzaepfel JH, Ezell HE. Sites of metastases of uterine carcinoma. Am J Obstet Gynecol 1955; 69: 1027-36; discussion 36-8. 